\title{
The (Un)Making of Suicidal Modernity: Giddens' Account
}

\author{
Pascal K. Kao \\ Department of Sociology, National Chengchi University, Taipei, Taiwan
}

Copyright $\bigcirc 2017$ by authors, all rights reserved. Authors agree that this article remains permanently open access under the terms of the Creative Commons Attribution License 4.0 International License

\begin{abstract}
This essay proposes to recover the political site of suicide that has been displaced by a reflexive turn of sociology since the 1980s. Considering Giddens' social theory to be an example of such displacement, we argue that his early analysis of suicide is a vanishing mediator of his late discourses on society and modernity. Giddens coined a unique type called attempted suicide to invert Durkheim's typology before forging a secret link between suicide and agency. In so doing, Giddens' own recursive construction of society transferred to the reflexive regulation of modernity, thus tacitly admitting that routine structures have been destabilized into runaway systems. When Giddens advanced his life politics of intimacy and climate change, suicidal agency even became a strategy of survival. In conclusion, although taking modernity to the reflexive limit of individualization, Giddens did not break with the philosophical reasoning of the subject and the sociological reality of the social.
\end{abstract}

Keywords Attempted Suicide, Suicidal Agency, Émile Durkheim, Reflexive Modernity, Life Politics

In a way, everybody must die twice... based on the difference between the two deaths: between the death in which I lose one of my lives and the ultimate death in which I lose the game itself. Slavoj Žižek, The Sublime Object of Ideology

Never had any imagining of death: it should remain a surprise. - Jean Baudrillard, Cool Memories V

\section{Introduction}

The current of suicide has been unable to stop changing ever since it crossed paths with the storm called modernity. Currently, intellectual history demonstrates that just as individual acts of suicide emerged to represent a social object at the expense of philosophical truth by the end of the $19^{\text {th }}$ century, so collective forms of suicide retreated to herald a political event after the demise of sociological law in the beginning of the $21^{\text {st }}$ century. In spite of this history, the putative death of sociology awaits a close examination.

Émile Durkheim's Suicide (1897) is a foundational text of classical sociology that made sociology a scientific discipline because societal forces that drove individual acts could be represented objectively with statistical and conceptual analysis. Joining Nietzsche and Freud, Durkheim launched a Copernican revolution against philosophy itself insofar as his socio-structural typology of suicide exposed the myth of voluntary death that had underlain the metaphysics of free will from Seneca to Kant. Thereafter, the discipline took pride in establishing a science of moral reality to replace the previous philosophies of regulative ideas.

Leaving moral philosophy behind, Durkheim's moral science of forces and types was destined to evolve with the societies that produced suicides. Hence, it is appropriate to acknowledge that after more than a century of research and debate regarding Durkheim's magnum opus, the social landscape and cultural background of suicide have been revamped. In particular, new statistical data indicate an inverse validity and perhaps the total unreliability of factors such as secularization, urbanization, divorce and widowhood, and economic unrest, which accounted for a higher suicide rate in Durkheim's Europe [1]. Today, in rethinking suicide as a social fact in the globalized world, we must concede from the beginning that the common rule of self-immolation as a moral taboo has disappeared together with the default factors of integration and regulation.

Paradoxically, just when the moral force of society receded, the immoral act of suicide advanced from the personal to the political stage. Through the lens of the Western media, since September 11, 2001, acts of suicide have transgressed the normal jurisdiction of social facts, propagating social anomalies beyond measure. However, historical precedents may be observed in the Japanese Kamikaze attacks of 1943-1945, Palestinian suicide bombers since 1981, and Sri Lanka's Black Tiger suicide 
cadres from 1987-1990 onwards [2]. With the addition of Al-Qaeda in 1988 and ISIS in 2014, these so-called suicide missions, manifested in the ideal type of no-escape attack, add an enigmatic political dimension to the personal act because these acts become publicly opposed to the social unconscious and explicitly embroiled in organizational structure, rational calculation and moral ambivalence (blending heroism with martyrdom and blurring altruistic sacrifice with collateral damage) [2, pp.v-x, 259-299].

To make sense of politicized suicide, a new generation of intellectuals turned to cultural history and economic semiotics for an understanding different from that provided by sociology and based in moral science. For example, Barbagli [3, pp.1-13, 67-71, 125-132] rejected Durkheim's structural typology for marginalizing the cultural factor and then argued that the containment of suicide rates in Europe was primarily dependent upon the influence of Christianity at the levels of religious belief, customary conduct and emotional expression within the civilizing processes of morality, politics, law and science. Distancing himself from sociology, Barbagli built on an interdisciplinary analysis of qualitative and quantitative data to propose an alternative typology. Categorized with the concept of interpersonal intention, "aggressive suicide" and "suicide as a weapon" were imported from the East and posited as two cultural antipodes to the egoistic and altruistic types of suicide in the West [3, pp.300-312].

Transcending cultural stereotyping, Berardi [4, p.154] submitted a humanist report about numerous high-profile cases of suicide and mass murder, or rather "suicide by cop...a kind of suicide by proxy", over the past several decades. After examining random killing sprees against "shared isolation" in Europe and America, "ultimate suicide" attacks for identity politics in the Middle East, mass youth suicides in Japan and corporate suicide epidemics in China, Berardi [4, pp.190-193] concluded his reflective journey with "the perfectly recombinant city" of Seoul in South Korea, which "has the highest suicide rate among OECD countries." At the heart of darkness, the smart city reveals the architectonics of a semiocapitalist society constructed by voluntary submission of cognitive labour to virtual capital. In the precarious society, cognitarians put their souls (of communicability) more than their bodies (of productivity) to work in the fractal time-space linked by mobile technologies [5, pp.74-105, 184-205]. In fact, the connective generation suffers from such biopolitical power to the extent of falling into a panic-depressive cycle before acting out deadly suicidal explosions with rage and hatred [6, pp.84-135]. Following Baudrillard's [7] allusion to "the revenge of the mirror people" on spectacle and simulation, Berardi [8, p.138] insisted, "The suicidal implosion has not been confined to the Islamists. Suicide has become a form of political action everywhere." Thus understood, "the present war between Western absolute capitalism and Islamic fundamentalism may be viewed as a war between Nazism and Fascism" [4, p.104].
With the benefit of hindsight, this paper claims that mainstream sociology has failed to honestly confront such ferocious politicization of suicide as a sign of our times. Theoretically, this failure is the result of a reflexive turn of sociology when social scientists conceded to a rallying cry around "second modernity" in an attempt to assimilate the philosophical debate over modernity and post-modernity in the 1980s. Anthony Giddens was one of the leading champions of a more reflexive modernization of society. He presented a comprehensive sociological project regarding how to engender systemic changes by the convergence of state power and individual agency, as long as those two players acquire mastery of risk assessment from within the social structure that exists virtually. Giddens' project lay in the vanguard of reflexive sociology and hence provided a favourable springboard from which to recognize the world-historic condition of suicide and modernity.

The essay reveals a restless spirit at the heart of Giddens' reflexive turn of sociology in the 1990s by returning to his positive reflection on suicide back in the 1960s. According to his prescient viewpoint, there is a singular phenomenon called attempted suicide that plays the role of acting otherwise, in which the suicidal agent aspires after liberalization of the self in the wake of social emancipation. Meanwhile, Giddens developed his theory of suicide in a counter-Durkheimian framework by resorting to perspectives from anthropology and social psychology, therefore transforming the suicidal act from a byproduct of the social structure into a catalyst of social change. After establishing a secret bond between reflexive sociology and the sociology of suicide in Giddens' work, this essay interprets and criticizes his "life politics" regarding the issues of intimate relationships and climate change insofar as those issues essentially redeploy the suicidal agency as a strategy of survival in a runaway world.

\section{Giddens contra Durkheim}

Giddens' theory of society may be considered one of several responses to a classical question regarding systemic integration compared with social integration, and his initial response was to fuse the opposite terms of structure and agency, terms that primarily represented British and European thinking, into a duality [9-15]. However, after shaking the solid ground of society with structural rules and resources that constrain and enable agency, Giddens [16-17] proceeded to destabilize the linear course of history with a reflexive model of modernity in which nation-states and individual selves operate as the principal agents of change. Some observant readers suggested that Giddens' radicalized vision of modernity reveals a change of accent, if not position, from recursive construction of societies in action to reflexive regulation of abstract systems [18, p.200-202; 19, p.138-142].

The obscure shift may be one of the reasons why critical 
commentaries on Giddens' work have been sufficiently divergent, ranging from eclecticism and revisionism regarding his theory of society to postmodernism and last modernism concerning his theory of modernity [20-24]. Disagreement aside, one common critique asserts that individual agency in Giddens' modern society is conducted by the principal faculty of cognition. To rectify this bias, much work has been performed to explicate the agency of an actual individual by stepping outside the bounds of cognitivism and exploring additional steering mechanisms, such as embodied technique, emotional culture, self-help practices and psychic identity [25-30].

We withhold judgment and a proposal before we identify the imagination of suicide that is embedded in Giddens' flowing image of social reality. We argue that his reflexive sociology represents an inversion of Durkheim's structural-functional sociology. In particular, after the fourfold typology was reduced to a singular type called attempted suicide, our sociologist went beyond his peers to foresee that the trial of suicide would be regarded as a special type of agency, thus propelling society into the orbit of reflexive modernization.

\subsection{Attempted Suicide}

Giddens began his study of suicide with myriad approaches in a series of research notes and essays beginning in 1964. In a short note, Giddens [31, p.115] displayed an interest in a type of attempted suicide that referred to death threats of "the individual [who] has a grievance" insofar as those threats "function independently as mechanisms of social sanctions". By that time, post-Durkheimian studies of suicide such as Erwin Stengel's Suicide and Attempted Suicide (1964) and Jack Douglas' Social Meanings of Suicide (1967) preferred contextual interpretation to causal explanation, elaborating on the deep play of meaningful perceptions implied in suicidal attempts with distinct methods, timings and locations [32]. Even then, Giddens' analysis extended beyond cultural hermeneutics.

His analysis underlined the paradox of the reflective and mechanical qualities manifested by attempted suicide and portrayed the act as an "accepted method of bringing pressure to bear upon others" and "an attempt bound to be saved" [31, p.116]. Empirically, Giddens culled examples from aboriginal cultures to demonstrate that suicidal threats in word and action could function as a type of public protest to demand criminal expiation or settle matrimonial disputes. Moreover, his analysis exhibited familiarity with both anthropological and psychoanalytical thinking because the terminology Giddens used was loosely related to the concept of ritual ("social sanction") and the model of the psyche ("pressure on others", "induce feelings of guilt and concern", and "desire to influence others") [31, p.115-116].

Admittedly, attempted suicide has no place in the fourfold typology constructed by Suicide. However,
Giddens brought the atypical act into full play to dismantle the presumption of social structure in Durkheim's analysis. If a type is called for, then attempted suicide may be subsumed in egoism or anomie for its rationalized features although the act also demonstrates the ritualized elements inherent in this type of altruism. The potential of attempted suicide to transgress the distinction of Durkheim's typology further suggests the coexistence of modernity and tradition as contradictory forces in a given society. Thus, we read the unusual statement, "There does exist another form of suicide, or a rather different type from 'altruistic' suicide, which is part of a wider social system of punishment and sanction in some societies" [31, p.115].

From the initial stage, Giddens [33, p.371; 34-35] chose social psychology to be his method of study, a method that focuses the analysis on the "interrelationship between personality and social structure". Concurrently, Giddens [36] applied the method of social psychology to a historical inquiry of the suicide problem in Durkheim's France. Giddens contended that Durkheim's Suicide should be appreciated for its theoretical rather than empirical breakthrough and that individual personality should be factored in with the help of biographical accounts of suicide to increase the explanatory power of social structure. Giddens [36, pp.11-12] resolutely rejected the "misconceived ontological dichotomy" created by Durkheim and Tarde and generously accepted conceptual models from both sociology and psychology to reconcile social forms with individual types.

Moving towards theory building, Giddens proposed his reflection on egoistic and anomic types in "A Typology of Suicide", which was published and republished in 1966 and 1971, respectively. In 1977, the same paper was heavily revised into "A Theory of Suicide" and published again. In "A Typology of Suicide", Giddens [37] justified the reduced scope of his topic by arguing that egoism and anomie are predominant in modern industrial society. Expanding on Durkheim's sociological method, Giddens sharpened the meanings of egoism and anomie by reporting on several suicide cases (an attempted suicide by self-poisoning and a competed suicide by hanging) and digressing to a discussion of Freudian psychoanalysis before concluding with the presentation of two flowcharts outlining various causal pathways leading to egoistic and anomic acts of suicide.

The essay ends with a dense passage [37, pp.116-117]. First, the altruistic type of suicide was dismissed as a remnant of traditional society, although a trace of some altruistic force appeared indispensable even after Giddens provided "anthropological evidence" from tribal cultures to disregard altruism as a concept. The essential distinction between modernity and tradition was questioned such that every suicide case could be categorized as egoism or anomie. Then, pace Maurice Halbwachs, any implication of sacrifice was excluded from the concept of suicide to account for the example of suicide committed by a monk 
who "consigns himself to the flames in a public and deliberate altruistic fashion". Once again, the example objectively comparable to altruism or sacrifice was understood to be unique "in other cases" and should thus be considered otherwise; in addition, the monk's act can be observed in "a less open form" in the modern types of egoism and anomie. Clearly, Giddens wanted to uphold attempted suicide as a virtual type wandering at the motivational centre of the real types of egoism and anomie in addition to the social unconscious. Simultaneously, Giddens wished to disconnect attempted suicide from sacrifice and altruism and yet identify a functional equivalence of religious or moral forces to account for that special type of demand or sanction in the act of attempted suicide.

In "A Theory of Suicide", attempted suicide grew into a full-blown type. In addition to Durkheim and Freud, Giddens [38] included additional theoretical views from authors such as Stengel, Douglas, Masaryk and Halbwachs. Stengel and Cook's Attempted Suicide (1958) was one of the earliest references that interested Giddens in the issue of attempted suicide. In contrast, his reviews of Stengel's and Douglas' monographs on suicide exude a critical tone. Against both writers who were detractors of Durkheim, Giddens [34, p.164; 39, p.266] defended the intrinsic value of social explanation. However, this is far from saying that Durkheim is beyond reproach. On the contrary, Durkheim and Douglas were both subject to a series of critical comments because Giddens' theory of suicide sought to reconcile causality and meaning. This goal led Giddens [38, pp. 301-304] to modulate the conceptual scope of suicide against two extremes, Douglas' maximalist explication (suicide is a purposeful action situated in a symbolic context with rich meanings) and Durkheim's minimalist delineation (suicide is "an act carried out by an individual that results in his death, where he knows that his act will have that result"). Giddens' double-edged revision resulted in the sense of meaning being extended to unintended knowledge and the sense of causality being restricted to knowledgeable agency [40, pp.118-119]. Simultaneously, the "psychological dynamics of suicide" can be reconnected with the "social condition", whereas the social condition is redeemed as the "outcome of rationalized processes of action" [38, p.312]. This concept is also why Giddens insisted that suicide is "probably almost universally preceded by" depression, although one cannot be certain of the reverse [38, p.308]. Consequently, egoistic and anomic types of suicide should first be considered "particular types of individual interaction" before being considered "types of social condition" [38, p.312].

In Giddens' theory of suicide, the conceptual priority of individual interaction most likely came from Masaryk and Halbwachs. For example, in an introduction to the English edition of Suicide and the Meaning of Civilization (1970) by Thomas Masaryk, Giddens [41] reconstructed a social history of mentality regarding suicide from the
Greco-Roman periods up to Masaryk's time, thus providing a more complete context in which to understand Durkheim's scientific work. Giddens [41, p.xli] indicated that the contemporaries of Masaryk and Durkheim were fascinated by suicide as a social problem because suicide represented the symptoms of modern civilization during a religious and moral decline. Giddens consistently agreed with Halbwachs' absorption of Durkheim's typology into an all-inclusive "way of life" insofar as the typology stands for "social isolation of the individual" in modern times [36, p.14; 42, pp.xvi-xx]. As an empirical factor, isolation was correlated only with egoism in "A Typology of Suicide". However, the same factor was raised to the level of a theoretical concept that accounts for both egoistic and anomic types of suicide in "A Theory of Suicide". In addition, there was a reflection about the possible link between isolation and egoism at the end of "The Suicide Problem in French Sociology", which was published and republished in 1965 and 1971; however, this particular passage was revised in the version published in 1977. Giddens must have read Halbwachs' analysis of isolation as a common principle of modern society to claim that "the social conditions implicated in the causation of suicide have to be closely bound up with the motivated, purposive character of human behaviors" [42, p.xx]. Thus, Giddens' theory of suicide presupposes Halbwachs' theory of civilization, in which an "isolated way of life" becomes severed from "collective memory" [42, p.xvi; 43, p.128].

From the historicist standpoint of isolation, we should understand attempted suicide as a singular type that is irreducible to the general law of society and the particular types of suicide. Recall the concluding passage in "A Typology of Suicide". Just as the distinction between the cases of attempted suicide by self-poisoning and completed suicide by hanging remained uncertain, so attempted suicide as an exceptional type could not yet identify itself inside these normative types of egoism and anomie. In the closing remarks of "A Theory of Suicide", a clarifying subtitle, "Suicide and Attempted Suicide", was added; in addition, an affirmative thesis stressing the constant element of risk taken in every act of suicide was developed. We are advised to recognize something "contingent, even intervening, between the attempt itself and its outcome" [38, p.321]. Perhaps the element of contingency can best characterize attempted suicide as a singular type wandering through the particular types of egoism and anomie like a haunting spectre. If so, then attempted suicide virtually underlies all types of suicide in modernity because of the increasingly isolated environment of interaction: "The social or moral isolation of the actor...helps to create his own social milieu at the same time as he is created by it" [38, p.314]. In a society in which risk-taking is applauded, isolation can establish a state of health rather than illness for individuals.

\subsection{Suicidal Agency}

In 1964, Giddens posed the question of attempted suicide using sketchy methods and concepts. By 1977, Giddens had 
proposed a typology and a theory of suicide. In addition to the sociology of suicide, Giddens also developed his sociology of action, which may be better understood as an inversion of Durkheim's sociology of structure. Structuration theory is founded on replacing Durkheim and Parsons' structural functionalism with Giddens' double hermeneutics. This new sociological method elucidates an individual's knowledge of his/her own actions with the aid of a grand theoretical synthesis of not only Marx and Weber but also Schütz and Garfinkel, Winch and Habermas [44]. In light of Giddens' early reflections on attempted suicide, his original contribution to the field of social theory will be examined in a directly related context of Durkheimian sociology.

Giddens [45-46] commented on Durkheim's work in two seminal essays regarding political sociology and moral individualism. These articles established the groundwork for his textbook introduction to Durkheim's sociological theory and his editorial collection of Durkheim's political analysis [40; 47]. It is worth considering whether Giddens' recognition of Durkheim's stance for moral individuals and against the socialist state affected his serial revisions of Marxian historical materialism. On a balance sheet, we understand that Giddens' centrist politics beyond Left and Right is the sensible choice after his critical reception of Durkheim and Marx. In this sense, the Third Way provides a prospective program for overcoming disillusionment with the false prophecies of scientific evolution and political revolution. Tilting the balance, we assume that Giddens' life politics expanded the horizon of social democracy envisioned in Durkheim's sociology of difference and identity more than in Marx's philosophy of conflict and contradiction. Manifested in his politics of intimacy and climate change, Giddens' politics of lifestyle choices should have had a great convergence effect on political, economic, social and technological rationalities, under which reflexive individuals, governing nation-states and interlocking organizations on local and global levels are predisposed to work in synergy for the actualization of common human values.

Regarding sociological theory, Giddens intended to reconcile a conflict of interpretation between the early and late works of Durkheim. Giddens overthrew the established opinion that Durkheim believed in contrasting images of modern society reflected by the prisms of biological differentiation and theological integration and accentuated instead the ignored importance of Durkheim's courses on education at Bordeaux from 1895 onwards [40, pp.16-19, 49-50, 63-64, 80-82]. According to that opinion, Durkheim changed his position regarding the organizing principle of modern society somewhere between Division of Labor in Society (1893) and The Elementary Forms of Religious Life (1912), as long as that principle transformed itself from the economic to the cultural domain in the specific sense that the collective consciousness of specialized labors yielded to the collective representation of unifying totems. Against the polarizing view, Giddens presented his distinct thesis that the lectures Durkheim delivered between 1895 and 1897 should be taken seriously as a missing link in the specious divide between a science of social change and a religious form of life. Durkheim expounded on how to establish authority and enforce sanctions by the institutional practices of the family, school, church and state.

In short, Giddens imposed a single vision on Durkheim by the late 1970s, hoping to supplant the double vision invented by Parsons. Until recent years, the double vision appears to have continued organizing the division of the functional, structural and cultural branches in the field of Durkheimian study [48, pp.1-31]. Nevertheless, it is not without significance that Durkheim simultaneously reflected on politics as moral education and suicide as a moral crisis. Once the circumstances are considered, we begin to see that Giddens could not rewrite the rules of sociological methods without the pretext of turning Durkheim's unclear transition into a definite position, and people who find themselves in such a position have learned to regard suicide not as a moral hazard but rather as a political chance for society itself to change.

As such, Giddens turned Durkheim on his head. As a consequence of admitting that attempted suicide is a certain political protest, Giddens must have established the goal of his sociological project to invert the elementary form of social life from moral order to immoral action. This position is also why Giddens not only criticized the linguistic turn but also denied any cultural turn in social theory. Giddens' reflexive sociology is foreign to both the structuralist and the counter-cultural schools of sociology in that Giddens cast doubt on their totalized visions of modernity, such as semiotic codification and symbolic desertification, from a more rational standpoint of action that promised to rebuild the base of society and constructively affect the course of history. Ultimately, Giddens' theory of suicide morphed into a theory of agency:

"Power relations are two-way. This accounts for the intimate tie between agency and suicide. Self-destruction is a (virtually) always-open option, the ultimate refusal that finally and absolutely cancels the oppressive power of others; hence suicidal acts themselves can be understood as concerned with the exercise of power" [49, p.149].

The unique coding of "suicide" with "agency" forecast the disappearance of the suicide problem in Giddens' work after 1980. Breaking sociology's old rules, Giddens [44, pp.138-141] criticized Durkheim's Suicide one last time, noting a defect inherent in the positivist method: the personal experience of suicide escaped the description of scientific language. With reference to Giddens' general sociology, the hidden link between suicide and agency was a vanishing mediator behind the horizon of the liberalization of the world running away from recursive society towards reflexive modernity. In Central Problems in 
Social Theory, Giddens [49, pp.123-130] endeavored to understand the empirical instability of the human psyche in critical situations. Giddens examined Le Bon's analysis of mob behavior and Bettelheim's discussion of the Nazi camps, recognizing the abnormalization of the psychological side of modernity. Reflexivity was defined there in terms of "reflexive self-regulation" in the midst of "interdependence of action" from the perspective of abstract systems [49, pp.53-59]. In The Constitution of Society, Giddens planned to overcome the conceptual contradictions of society in time-space, such as agency and structure, reproduction and change. He examined the symbolic interactionist and ethnomethodological discourses of everyday life, thus reconfirming the routinization of the anthropological side of modernity. Reflexivity was defined there in terms of "reflexive monitoring of action" from the perspective of rational individuals. Confined to the recursive loop, the individual action's unconscious motivation and unintended consequence remain conducive more than obstructive to the maintenance of collective practices, namely social systems [16, pp.5-14, 41-45, 78-83].

Consequently, it is reasonable to expect a brief encounter of the two voices of reflexivity represented by autonomous individuals and unbridled systems in The Consequences of Modernity:

"All human beings routinely 'keep in touch' with the grounds of what they do as an integral element of doing it. I have called this elsewhere the "reflexive monitoring of action"... This is not the sense of reflexivity which is specifically connected with modernity, although it is the necessary basis of it" [50, pp.36-37].

Yet reflexivity's ventriloquism is bound to fail beyond a point of no return. The construction of recursive society not only allows the actual power of agency to revamp social structures but also releases a potential force of suicide to erode social relations, whereas it is social relations that breathe vital values into structural rules and resources. Therefore, in his Reich lecture, Giddens [51] forewarned us that once we admit that "manufactured risks" have brought the world of tradition and nature to an end, we should take one more step to expect the unexpected "new riskiness to risk". The second level of risk consciousness bears witness to the outer limits of reflexive monitoring of action and must have conceded to a more lucid voice saying that the positive society mastered by individual reflexivity has taken a turn, even a leap, towards a suicidal modernity governed by system reflexivity. Thus, if Giddens [50, pp.151-154] imagined that reflexive modernity is like "riding the juggernaut" but did not identify the chief riders, then the juggernaut was most likely running about wildly by itself.

Battles over de-regulation and re-regulation eventually escalate into uncertainty. "We are surrounded by areas where we don't really know what we have done to [the] existing order of things and what the consequences will be" [43, p.114]. Crossing this eventual point, uncertainty is destined to settle for a de-realization of the world as "scenario futures", which will occur in "a number of alternative possible worlds" [52, pp. 244-245]. The future scenarios could be imagined by means of the narration of the self and the planning of the state since Giddens spared no effort to reassure us with his life politics of intimacy and climate change. However, driven by a death wish, futures beyond the limits of human imagination can also be realized. In today's world, reality is often stranger than fiction. Reality may have become a fabulous recounting of the world by itself.

\section{How Is Life Politics Suicidal?}

We have demonstrated that Giddens' counter-Durkheimian interpretation of suicide should unlock a constructive concept of agency as an official mediator of his reflexive theories of society and modernity; however, the secret coding process breaks down before the transmutation of suicidal modernity as a survival machine. Next, the disjunctive link between suicide and agency must be placed into context by referring to Giddens' politics and policy proposals. From his empirical discourses on intimacy and climate change, we may discover how life politics works with and against suicide in a psychoanalytic sense of disavowal.

When presented together, the transformation of intimacy and the amelioration of climate change belong to the priority agendas of life politics. Giddens [17, pp.210-217] defined life politics in contrast to emancipatory politics in that the former is interested in self-actualization with the personal choice of lifestyles, whereas the latter is concerned with fighting against imposed external constraints, such as exploitation, inequality and oppression, and aspiring after collective liberation sustained in justice, equality and participation. Life politics in a post-traditional society is supposedly distinguished from the established ideologies of modern politics. When examined separately, the creation of personalized democracy with the flowering of intimacy depends primarily on the communication of loving individuals, whereas the invention of sustainable development against the catastrophe of climate change is primarily decided by the negotiation of powerful nation-states. Before we reconsider the ironic strategies of the individual and the state, we should take a step back to inspect the construction site of life politics. This site emerges at the juncture of abstract systems and the reflexive self as a consequence of modernity.

For Giddens [50, p.114], the transformation of intimacy exhibited a "direct (although dialectical) connection" with the growth of abstract systems. The connection in question is indicated in the two forms of trust, one form in systems and the other form in persons. Giddens $[50$, p.120] then 
insisted that "it is quite wrong, however, to set off the impersonality of abstract systems against the intimacies of personal life as most existing sociological accounts tend to do". It is crucial to note here that Giddens had reconceived the paradox of personal trust and systemic trust as a form of time (eternal and periodic) instead of being (abstract and concrete). Therefore, the formal paradox of trust can be resolved by means of temporalization if we recognize that the achievement of intimacy lies in taking the project of reflexive modernity into the hands of the self:

"Trust on a personal level becomes a project, to be 'worked at' by the parties involved, and demands the opening out of the individual to the other... Personal trust, therefore, has to be established through the process of self-inquiry: the discovery of oneself becomes a project directly involved with the reflexivity of modernity" [50, pp.121-122].

Nonetheless, the journey of self-discovery is not without tribulations. The self must not only project his/her personal futures in the midst of dilemmas such as unification versus fragmentation and authority versus uncertainty but also protect him/herself against "the threat of meaninglessness" as "an underlying dynamic". However, the self must come to terms with the nihilistic current of modernity by harnessing self-destructive forces to transform society. Henceforth, "the more open and general [the] reflexive project of the self, as further fragments of tradition are stripped away, the more there is likely to be a return of the repressed at the very heart of modern institutions" [17, p.202]. Because modern institutions are typically based on the hospital, prison, the family, church and state, the return of the repressed is expected to induce deinstitutionalization of childbirth and death (in particular, dying of old age and illness), criminality and madness, sexuality and love, inherited and invented traditions, fundamentalist and spiritualist religions, and finally new social movements, such as the peace and ecological movements [17, pp.202-208].

Given the tribulations, Giddens construed life politics to be an odyssey of homecoming in which the self has undergone a near-death experience. It is on the perilous site of self-experience that we can listen to Giddens' political discourses on intimacy and climate change with suspicion as if they were Odysseus narrating his adventures. What is prominent in these adventures is a final return of the repressed qua death by suicide. However, this return is in fact a penultimate return because the repressed death returns in the dissimulated form of attempted suicide. Yet again, the protest of attempted suicide is codified as a protestation of individual agency to fulfil a reflexive project of the self.

Giddens' diagnosis of late-modern intimacy as the democratization of personal life is often criticized for painting an overly utopian picture because of his disregard for actual inequality within personal relationships, particularly when those relationships concern the female gender and the aging body [53, pp. 37-42, 172-175; 54, pp.140-141]. This line of interpretations contributes to a misleading impression that Giddens' optimistic projection must have undermined the validity of his analysis of intimacy. This criticism is unfounded, however, because Giddens covered a complicated set of problems as a result of the reflexive transformation of intimacy. For example, problems may occur when plastic sexuality spins beyond the reflexive control of an interdependent relation and falls under the addictive cycle of a codependent fixation and when pure relationships run into an internal contradiction to create "new emotional antagonisms", particularly rage between the sexes $[55$, pp.89, 153]. Therefore, from the vantage point of suicide, we can argue instead that Giddens' problem lay in his overly realistic compromise with the late-modern lifestyle. That is to say, suicide is attempted primarily as a homeopathic survival strategy. Recognizing the strategy may help us understand why Giddens' historical account and theoretical review of the transformation of intimacy must follow a tortuous path.

In his historical account, Giddens sought to balance the forces of plastic sexuality and confluent love for the establishment of pure relationships. Plastic sexuality refers to the separation of sexual pleasure from the end of phallocentric reproduction. Plastic sexuality represents a direct achievement of technical innovation (applications of contraception and in vitro fertilization) and cultural revolution (acceptances of femininity and homosexuality) [55, pp.23-34, 140-144]. Conversely, confluent love refers to "active, contingent love" by "opening oneself out to the other", provided the couple interacts with "equality in emotional give and take" [55, pp.61-64]. Confluent love represents the next advancement of the projective imagination of female culture (the literary history of romanticism) and a therapeutic remembrance of object-related psychology (the social history of motherhood) [55, pp.41-47, 111-132]. However, pure relationships do not automatically come to fruition when the conditions of plastic sexuality and confluent love are socially satisfied. Post-familial couples must also overcome a near-death experience before achieving a pure relationship and confront further contradictions, the first and foremost being commitment until further notice.

The late-modern couple must work on changing their possibly codependent relationship into a relationship of interdependence. This necessity exists because of the prevalence of addiction in reflexive modernity: "Once institutional reflexivity reaches into virtually all parts of everyday social life, almost any pattern or habit can become an addiction" [55, p.75]. Facing the pathology of addiction as a consequence of reflexivity, reflexivity is reintroduced as the therapy: "Addictions, then, are a negative index of the degree to which the reflexive project of self moves to centre-stage in late modernity"; "reflexivity is a necessary condition for emancipation from addiction, not a sufficient one. None the less, the behavioral importance of such 
programming is evident enough" [55, pp.76, 92]. If reflexivity is partially responsible for both the illness and the cure of addiction, then addiction is not mere poison and nor is reflexivity pure medicine. Thus, the metamorphosis of a relationship cannot be guaranteed by a valid distinction between addiction and reflexivity but rather depends on the addictive couple battling against and for reflexivity indeterminately.

In his theoretical review, Giddens sought to replace the bio-politics of sexuality with a life politics of intimacy by sending Foucault back to dialogues with not only Freud and Klein but also with Reich and Marcuse [55, pp.111-132, 158-172]. Basically Giddens invoked those psychoanalytic and Marxist discourses to recognize the transformative power of sexual libido as long as the libidinal energy can exploit death instincts to create an erotic civilization comprised of reflexive rather than confessional selves. According to the goal of achieving the non-repressive civilization of Eros, Giddens' reflexive project can be deemed to be implementing Marcuse's aesthetic proposal in the spirit of Fourier:

"For Marcuse, as for Freud, the death instinct is not a wholly destructive force. Human creativity is a consequence of a fusion of life and death instincts, and the problem with modern civilization is that the death instinct has become detached from its necessary interaction with libidinal energy... So far as political energy goes, Charles Fourier has more to teach us than Marx. Pleasurable cooperation based on attraction passionée, not passionate love but the flowering of Eros in communicative love and friendship, would become the dominant medium of sociability" [55, pp.167-168].

We may observe a similar logic of playing at death for survival in Giddens' politics of climate change. From the outset, it is beyond question that Giddens continued to distance himself judiciously from every form of idealism. Giddens acknowledged the precautionary principles of green activists and the catastrophic premonitions of doomsayers, similar to his acknowledgement of the projective expectation of romantic love as a narrative synthesis of religious love and passionate love [55, pp.37-47; 56, pp.22-31, 49-60]. However, things only became interesting, or rather serious, for our sociologist after he took a realistic look at human destruction of nature, against which he provided some reflexive sociological measures for achieving sustainable development [56, pp.73-90]. Consequently, Giddens recommended "backcasting planning" and "proactive adaptation" to benefit the decision-making process in environmental policies. These modernist concepts (planning and adaptation) were revised by a sort of reflexive qualification (backcasting and proactive) to adopt a suicidal strategy for survival.

The defining dynamic in the strategy is the constant destruction and construction of the future that one imagines oneself to be a part of. Because planning is inevitable for logical and historical reasons (because one begins systematic thinking about the future and inherits the counter-revolution of privatization from the 1980s), backcasting planning takes one step up to manage unpredictability by letting the imagined future perish and revive as "alternative and plural futures, where adjustments, even radical revisions, are made as time unfolds and then built into other scenarios" [56, pp.98-99]. Conversely, because adaptation was originally a precautionary doctrine after the event, proactive adaptation takes one step forward to pre-empt an orientation to possible futures by strengthening resilience to vulnerabilities, which is "understood not only as looking for vulnerabilities and blocking them off, but as investigating also what the knock-on consequences of mitigation strategies are likely to be" [56, p.165].

At this point, we can reiterate that Giddens' problem lay in his overly realistic reconciliation with the late-modern world order. The problem is his unapologetic employment of power to make things work at the price of downplaying the differentiated operations and often contradictory rationalities of society, science and politics. We are specifically referring to the mass mediatization of society, science and politics as long as they are equivalently embroiled in an ecological communication. Regarding society, Giddens $[56$, pp.7, 12] conceded for a moment that "the risks from climate change [sic] constitute only one set of worries among others... for example, pandemics, international terrorism and the spread of nuclear weapons". Regarding science, Giddens admitted in passing that risk calculation is dependent on the context of scenarios and that risk perception is interrelated with the framing of messages [56, pp.32-34]. Regarding politics, Giddens expected the reformation of an "enabling state" to take a secondary position by simply ensuring that inspirational entrepreneurs and local governments were capable of acting together to identify innovative solutions for the environmental crisis [56, pp.125-128].

In contrast with his utopian aspirations, we actually find ourselves deep in the mud of real politics [57, pp.176-185; 58, pp.167-173]. In Giddens' defence, the short-sightedness of the unregulated markets could be prevented by oversight from the regulating nation-states, although Giddens appeared reluctant to acknowledge that some extremely powerful states may undermine the national sovereignties of other countries and their own by facilitating political and economic interests to converge on implementing eco-friendly solutions, such as production of clean energy and reductions in carbon emissions. Moreover, these states could theoretically argue for the agenda of climate change as a post-ideological mask but practically collude with extra-juridical agents to influence, or even coordinate, flows of investment, donations, public opinion and policy decisions among industries, foundations, mass media and 
governments at regional, national and international levels. In sum, when a democratic state begins to openly play the role of an enabler to the spectral metastases of capitalism by utilizing technological tools and exploiting ecological crises, political corruption has erased institutional specificity and thereby lost moral accountability [59; 60, pp.45-95; 61, pp. 327-352].

In the final analysis, Giddens' politics of climate change moves away from the emancipatory politics of ecological movements only to slide into a synergistic domain of life politics and state politics [50, pp.157-159]. This phenomenon explains why Giddens built his entire analysis on the image of "SUV drivers" as an example of the "Giddens' paradox" (i.e. people disregard the invisible future until the future arrives as a visible catastrophe), as if the issue of climate change resided in the same order of lifestyle choices as intimate relationships [56, pp.1-3, 10, 102, 230]. Simultaneously, the evaluations and suggestions Giddens provided were all addressed to those "ensuring states" and "policy entrepreneurs", as if Giddens expected the political and intellectual elite to conflate their interests and combine the efforts of governments, businesses and NGOs to combat climate change.

Looking back, we have reason to suspect that Giddens' discourses on intimacy and climate change were far from value-neutral and sided with the power of disciplinary knowledge to shape a politics of self-actualization. Self-fulfilling his own prophecy for the rise of reflexivity, Giddens' empirical concerns between the 1990s and 2000s accelerated the decrease in the exchange rate of ideological currency until that rate reached zero. In this state, the tolerance for human plurality and deference to the singular earth established the incontestable rules of political correctness for liberal democracies today. Giddens' involvement in British politics further delegitimized the already tenuous division of labor between science and politics. His Third Way could be interpreted as a model for the politics of sympathy, literally defined here as a passion for the self before loving the other as one's self. For the model, the purpose of politics ends in social issues, and the struggle of life is to procure equal rights for all human and non-human beings. Coincidentally, the Blair/Cameron and Clinton/G.W. Bush administrations increasingly responded to the bubbling effects of the neoliberal turn begun in the 1980s from an elusive centre behind the bipartisan rhetoric. Therefore, what if the centrist response counted for nothing but the conformation of social worlds to the restoration of economic systems begun by the Reagan and Thatcher administrations? And what if Giddens' sociological theory and political practices represented a fellow traveler with the juggernaut of reflexive modernity, manufacturing the neoliberal individual who is in constant self-disavowal [62-64]?

\section{Conclusions}

Giddens [65] admitted that the sociological concept of society had been actualized as a nation-state in the modern world. The sociologist also insisted that nation-states will increase in strength rather than wither away against the tidal waves of globalization. This special position was derived from his historical account of the industrialization of wars and the internationalization of states, which essentially illustrated that the political nature of systemic reflexivity lay in the governmental power of positive knowledge instead of the sovereign reasons for personal rule and social contracts. In the political context, the aforementioned "necessary basis" of systemic reflexivity depends less on the "reflexive monitoring" of individual actions than on the "dialectic of control" by state powers. In short, the institutional consequence of modernity leads primarily to knowledge/power of the state rather than to knowledgeable agency of the self.

When portraying the nature of the juggernaut in late modernity, Giddens emphasized "unintended consequences" as opposed to "design faults" and "operator failure", which remain subject to the normative idea of high modernity. These consequences were ascribed to the reflexive circularity of social knowledge and the differential roles of power and value [50, pp.151-154]. In his words, "new knowledge (concepts, theories, findings) does not simply render the social world more transparent, but alters its nature, spinning it off in novel directions. The impact of this phenomenon is fundamental to the juggernaut-like quality of modernity and affects socialized nature as well as social institutions themselves" [50, p.153].

Regarding Giddens' ultimate apology for institutions, the preponderance of realism over utopianism cannot be more distinct. His counter-Durkheimian sociology of suicidal agency became ironically complicit with the Durkheimian politics of social organization, consequently breaking with Weber and extending beyond Marx. Conceding Weber's critical reason against bureaucracy, Giddens nevertheless appreciated Durkheim's positive vision for organization: "Organization produces areas of autonomy and spontaneity — which are actually often less easy to achieve in smaller groups. We owe this counter-insight to Durkheim as well as to subsequent empirical studies of organizations" [50, p.138]. "We must keep the Marxian principle that avenues for desired social change will have little practical impact if they are not connected to institutionally immanent possibilities... We must balance utopian ideals with realism in much more stringent fashion than was needed in Marx's day" [50, p.155]. "The outlook of utopian realism recognizes the inevitability of power and does not see its use as inherently noxious. Power, in its broadest sense, is a means of getting things done." [50, p.162].

Proceeding from the question of suicide, we arrive at the problem of realism at the bottom of Giddens' reflexive sociology. If such occurs, then both advocates and critics of 
his project of second modernity as a utopian dream have misdirected their emphasis. We must take one last look at Giddens' theory of society to emphasize what exactly was wrong with his realism. The constitution of a Giddensian society was amended to the reign of individual reflexivity after the decline of collective morality. However, a fundamental flaw is that the premise of the subject within the conception of late modern individuals remains an early modern concept:

"The problem with theorists of risk society is thus that they underestimate the radical character of this change: with all their insistence on how, in today's risk society, reflexivity is universalized, so that Nature and Tradition no longer exist, in all their talk about 'second Enlightenment' doing away with the naïve certainties of the first wave of modernization, they leave intact the subject's fundamental mode of subjectivity: their subject remains the modern subject, able to reason and reflect freely, to decide on the select his/her set of norms, and so on" [66, p.342].

On the Kantian plane of "subjective objectivity", one could already foresee that "all-pervasive renaturalization is strictly correlative to the global reflexivization of our daily lives" [67, p.158; 68, p.10]. Certainly, this renaturalization is what happens to Giddens' life politics of intimate relationships and the state politics of climate change. In any case, the politics of reflexive modernization is far from radical because the concept "brings us back to the first and only way - the Third Way is simply global capitalism with a human face" [68, pp.62-63].

Moreover, a supplementary flaw is that Giddens' realism harbored a belief in sociological rationality irrespective of the fact that reflexive modernity has supposedly engendered the individualization of society. In this case, our disenchanted sociologist succumbed to the simulation of social reality as a strategy of deterrence. This strategy protects us from the fatal shock of the implosion of the social into the masses:

"The mass is without attribute, predicate, quality or reference. This is its definition, or its radical lack of definition. It has no sociological 'reality'. It has nothing to do with any real population, body or specific social aggregate. Any attempt to qualify it only seeks to transfer it back to sociology and rescue it from this indistinctness which is not even that of equivalence (the unlimited sum of equivalent individuals: $1+1+1-$ such is the sociological definition), but that of the neutral, that is to say, neither one nor the other (ne-uter)" [69, p.38].

The inertia of the silent masses represents the organic extermination of the social succeeding to the subject and alludes to the genetic engineering of indifferent individuals homologous to unicellular clones. Because "the only thing cloning enshrines [sic] is the reiteration of the same: $1+1+1+1$, etc. ... It means that the individual is now nothing but a cancerous metastasis of his basic formula" [70, pp. $116,119]$.

"For this to happen, there is no need for a death drive, a biological nostalgia for a state prior to individuation and sex: it is our modern, paradoxical condition which produces this denial of self, this mortiferous repulsion... The modern individual, being no longer part of an order greater than himself, but a victim of his own will-commanded to be what he wants and to want what he is-ends up resenting himself, and, as a consequence, frittering himself away in the exhaustion of his possibilities: a new form of voluntary servitude" [71, pp.46-48].

Giddens cannot receive this insight into the monochromatic Xerox of individuals because his reflexive sociology holds up a mirror between the determinant bodies of the individual and the social only to continue chasing the indeterminate shadows of subjectivity and objectivity. Ultimately, Giddens' easy and final solution of sociology becomes a cautionary tale: the lesson is we cannot understand the precarious world of random suicide and mass murder around us without breaking the self-referential mirror. In front of mirror fragments, we begin to traverse the transcendental fantasies of the subject who can resist to metaphysical subjectivity or else short-circuit the transmediating screens among the masses who may escape from positivist objectivity. Once passing through to the other side of the mirror, we rediscover a cruel yet graceful place of sacrifice adjacent to suicide.

\section{REFERENCES}

[1] Pickering, W. S. F. and Walford, G. (eds) (2000). Durkheim's Suicide: A Century of Research and Debate. London: Routledge.

[2] Gambetta, D. (ed) (2005). Making Sense of Suicide Missions. Oxford: Oxford University Press.

[3] Barbagli, M. (2015[2009]). Farewell to the World: A History of Suicide. Cambridge: Polity.

[4] Berardi, F. (2015). Heroes: Mass Murder and Suicide. London: Verso.

[5] Berardi, F. (2009a). The Soul at Work: From Alienation to Autonomy. Los Angeles: Semotext (e).

[6] Berardi, F. (2009b). Precarious Rhapsody: Semiocapitalism and the Pathologies of the Post-alpha Generation. New York: Minor Compositions.

[7] Baudrillard, J. (1996[1995]). The Perfect Crime. London: Verso.

[8] Berardi, F. (2011). After the Future. Edinburgh: AK Press. 
[9] Lockwood, D. (1976). 'Social integration and system integration', in G. K. Zollschan and W. Hirsch (eds) Explorations in Social Change (pp.370-383). London: Routledge.

[10] Habermas, J. (1987[1981]). The Theory of Communication Action, Vol. 2: Lifeworld and System. Boston: Bacon Press.

[11] Archer, M. S. (1995). Realist Social Theory: The Morphogenetic Approach. Cambridge: Cambridge University Press.

[12] Archer, M. S. (1996). 'Social integration and system integration: developing the distinction', Sociology, 30: 679-699.

[13] Mouzelis, N. (1995). Sociological Theory: What Went Wrong? London: Macmillan.

[14] Mouzelis, N. (1997). 'Social and system integration: Lockwood, Habermas, Giddens’, Sociology, 31: 111-119.

[15] Collins, R. (1992). 'The romanticism of agency/structure versus the analysis of micro/macro', Current Sociology, 40(1): $77-97$.

[16] Giddens, A. (1984). The Constitution of Society: Outline of the Theory of Structuration. Cambridge: Polity.

[17] Giddens, A. (1991). Modernity and Self-Identity: Self and Society in the Late Modern Age. Cambridge: Polity.

[18] Shilling, C. (1993). The Body and Social Theory. London: Sage.

[19] Layder, D. (1994). Understanding Social Theory. London: Sage.

[20] Dallmayr, F. (1982). 'The theory of structuration: a critique', in A. Giddens (ed) Profiles and Critiques in Social Theory (pp. 18-27). London: Macmillan.

[21] Hirst, P. (1982). 'The social theory of Anthony Giddens: a new syncretism', Theory, Culture and Society, 1(2): 78-82.

[22] Craib, I. (1986). 'Back to utopia: Anthony Giddens and modern social theory', Radical Philosophy, 43: 17-21.

[23] Layder, D. (1987). 'Key issues in structuration theory: some critical remarks', Current Perspectives in Sociology, 8: 25-46.

[24] Meštrović, S. (1998). Anthony Giddens: The Last Modernist. London: Routledge.

[25] Shilling, C. and Mellor, P. A. (1996). 'Embodiment, structuration theory and modernity: mind/body dualism and the repression of sensuality', Body and Society, 2(4): 1-15.

[26] Shilling, C. (1997). 'The undersocialised conception of the embodied agent in modern sociology', Sociology, 31(4): 737-754.

[27] Williams, S. J. (2001). Emotion and Social Theory: Corporeal Reflections on the (Ir) rational. London: Sage.

[28] Groarke, S. (2002). 'Psychoanalysis and structuration theory: the social logic of identity', Sociology, 36(3): 559-576.

[29] Adams, M. (2003). 'The reflexive self and culture: a critique', British Journal of Sociology, 54(2): 221-238.

[30] Elliott, A. (2005). 'The constitution of the subject: primary repression after Kristeva and Laplanche', European Journal of Social Theory, 8(1): 25-42.

[31] Giddens, A. (1964). 'Suicide, attempted suicide, and the suicidal threat', Man: A Record of Anthropological Science, 64: 115-116.

[32] Taylor, S. (1982). Durkheim and the Study of Suicide. London: Macmillan.

[33] Giddens, A. (1965a). 'The present position of social psychology', British Journal of Sociology, 16: 365-372.

[34] Giddens, A. (1965b). 'Suicide', British Journal of Sociology, 16: $164-165$.

[35] Giddens, A. (1965c). 'Theoretical problems in the sociology of suicide', Advancement of Science, 21: 522-526.

[36] Giddens, A. (1965d). 'The suicide problem in French sociology', British Journal of Sociology, 16: 3-18.

[37] Giddens, A. (1971[1966]). 'A typology of suicide', in A. Giddens (ed) The Sociology of Suicide: A Selection of Readings (pp. 97-120). London: Frank Cass. Reprinted from Archive Europeénes de Sociologie, 7: 276-295.

[38] Giddens, A. (1977). 'A theory of suicide', in A. Giddens (ed) Studies in Social and Political Thought (pp. 297-321). London: Hutchinson.

[39] Giddens, A. (1969). 'Book review: The social meanings of suicide', Sociology, 3: 265-266.

[40] Giddens, A. (1978a). Durkheim. London: Fontana.

[41] Giddens, A. (1970). 'Introduction', in T. G. Masaryk, Suicide and the Meaning of Civilization (pp. xix-xli). Chicago: University of Chicago Press.

[42] Giddens, A. (1978b). 'Foreword', in M. Halbwachs, The Causes of Suicide (pp. xvi-xx). London: Routledge.

[43] Giddens, A. and Pierson, C. (1998). Conversations with Anthony Giddens: Making Sense of Modernity. Cambridge: Polity.

[44] Giddens, A. (1993[1976]). New Rules of Sociological Method: A Positive Critique of Interpretative Sociologies. Cambridge: Polity.

[45] Giddens, A. (1971a). 'Durkheim's political sociology', Sociological Review, 19: 477-519.

[46] Giddens, A. (1971b). 'The individual in the writings of Emile Durkheim', Archive Europeénes de Sociologies, 12: 210-228.

[47] Giddens, A. (ed) (1986). Durkheim on Politics and the State. Cambridge: Polity.

[48] Alexander, J. and Smith, P. (eds) (2005). The Cambridge Companion to Durkheim. Cambridge: Cambridge University Press.

[49] Giddens, A. (1979). Central Problems in Social Theory: Action, Structure and Contradiction in Social Analysis. London: Macmillan.

[50] Giddens, A. (1990). The Consequences of Modernity. Cambridge: Polity.

[51] Giddens, A. (1999). Runaway World: How Globalization is Reshaping Our Lives. London: Profile. 
[52] Giddens, A. (2001). 'A dialogue with Anthony Giddens', in C. Bryant and D. Jary (eds) The Contemporary Giddens: Social Theory in A Globalizing Age (pp. 229-270). Basingstoke: Palgrave.

[53] Jamieson, L. (1998). Intimacy: Personal Relationships in Modern Societies. Cambridge: Polity.

[54] Turner, B. S. and Rojek, C. (2001). Society and Culture: Principles of Scarcity and Solidarity. London: Sage.

[55] Giddens, A. (1992). The Transformation of Intimacy: Sexuality, Love and Eroticism in Modern Societies. Cambridge: Polity.

[56] Giddens, A. (2009). The Politics of Climate Change. Cambridge: Polity.

[57] Kaspersen, L. B. (2000). Anthony Giddens: An Introduction to A Social Theorist. Oxford: Blackwell.

[58] Loyal, S. (2003). The Sociology of Anthony Giddens. London: Pluto Press.

[59] Klein, N. (2007). The Shock Doctrine: The Rise of Disaster Capitalism. London: Penguin.

[60] Baudrillard, J. (2008[1983]). Fatal Strategies. Los Angeles: Semiotext (e).

[61] Žižek, S. (2010). Living in the End Times. London: Verso.
[62] Dardot, P. and Laval, C. (2014a). 'The new way of the world, Part I: Manufacturing the neoliberal subject', E-Flux Journal, 51: n.pag.

[63] Dardot, P. and Laval, C. (2014b). 'The new way of the world, Part II: Performance/pleasure apparatus', E-Flux Journal, 52: n.pag.

[64] Gane, M. (2015). 'The cultural logic of neoliberalism: Baudrillard's account', Cultural Politics, 11(1): 1-17.

[65] Giddens, A. (1985). The Nation-State and Violence. Cambridge: Polity.

[66] Žižek, S. (1999). The Ticklish Subject: The Absent Centre of Political Ontology. London: Verso.

[67] Žižek, S. (1997). The Plague of Fantasies. London: Verso.

[68] Žižek, S. (2000). The Fragile Absolute, or Why is the Christian Legacy Worth Fighting For? London: Verso.

[69] Baudrillard, J. (2007[1978]). In the Shadow of the Silent Majorities or the End of the Social. Los Angeles: Semiotext (e).

[70] Baudrillard, J. (1993[1990]). The Transparency of Evil. London: Verso.

[71] Baudrillard, J. (2001[1999]). The Impossible Exchange. London: Verso. 